\title{
The sustainability of the ACA: Legal challenge and legislative opposition
}

\author{
Ilaria Di Gioia, Birmingham City University, UK
}

\begin{abstract}
Universal health care coverage has long been seen as an unattainable goal for Americans. With the Affordable Care Act, the Obama administration addressed the issue with a complex system of mandates, subsidies, and state marketplaces. The implementation of the reform encountered many obstacles: legal challenges, congressional shut down, system failure, and recently, a growing number of state legislatures (23 to date) enacting measures to nullify or opt out of the reform. This paper examines the resistance to the Act in two interrelated dimensions: legal challenges and state legislative opposition. These two dimensions of resistance are explored in order to speculate on the legal and political sustainability of the reform. Ultimately, the discussion on the sustainability of health care reform sheds considerable light on broader sustainability of federal intervention in social policies (gun control, abortion, immigration, death penalty, drug control).
\end{abstract}

Keywords: Health Care Reform-Legal Sustainability-Political Sustainability

\section{Introduction}

U niversal health care coverage has long been a tantalizing prospect for Americans. In 2010, the Obama administration reformed the private insurance market creating a complex system of mandates, subsidies and state marketplaces, the so called "Obama Care reform", passed in Congress as the Patient Protection and Affordable Care Act ("ACA"). ${ }^{1}$ The main objective of the reform was to promote equality of access and extend affordable coverage to the uninsured. This paper analyses the role played by sophisticated legal challenges and state political opposition ${ }^{2}$ in undermining the full achievement of that objective. On one hand, legal challenges induced the Supreme Court to find compromises that transformed the original functioning of the Act; on the other hand, states have created legislative obstacles to the operation of the law within their boundaries. The political challenge, as of today, is to build up an effective cooperation between central government and the states for a uniform and equal implementation of the law.

The sustainability of the reform is therefore discussed from two perspectives:

1. the "legal" sustainability, by which I mean the ability of the ACA to withstand the legal challenge of unconstitutionality over a period of time. I examine the major legal challenges to the reform and the subsequent "compromises" found at judicial level, ultimately resulting in states being granted flexibility in the implementation of core provisions of the law and therefore in a remarkably heterogeneous operation of health care programs across the country;

2. the "political" sustainability, by which I mean the ability of the administration to protect the reform from the unceasing attacks of the Republican party but, above all, to deal with the reluctance of some states to co-operate with the federal government.

\footnotetext{
${ }^{1}$ Patient Protection and Affordable Care Act of 2010, Pub. L. No. 111-148, 124 Stat. 119, amended by Health Care and Education Reconciliation Act of 2010, Pub. L. No. 111-152, 124 Stat. 1029.

${ }^{2}$ The opposition is particularly fierce in the southern states where the revival of states' rights took the shape of an ideological battle for the protection of the founding principle of individual liberty. Conservatives argue that the core provision of the reform (the "individual mandate") is an alleged violation of economic liberty and have utilized constitutional principles as the structural matrix of their political goals.
} 


\section{The "legal sustainability" dimension}

The reform has been challenged three times before the Supreme Court. The challenges aimed at repealing specific provisions of the Act but the Court saved the reform resolving the controversies with a compromise, a small concession and an assertive decision:

1. National Federation of Independent Business v. Sebelius ${ }^{3}$ was the biggest compromise. The Court upheld the constitutionality of the Act in June 2012 but invalidated the Medicaid penalty provision, allowing each state to decide whether to expand its Medicaid program;

2. Burwell v. Hobby Lobby Stores ${ }^{4}$ was a small concession to the opposition. The Court considered the validity of the contraceptive mandate in June 2013 and ultimately upheld the plaintiffs' claims rejecting the contraceptive mandate for some religious family-owned corporations;

3. King v. Burwell ${ }^{5}$ was an assertive decision of the Court that strongly supported the reform. The Court allowed the federal government to provide tax credits and subsidies to low-income citizens to buy health insurance not only in state-established exchanges but also in federal-established exchanges. The Act has ultimately demonstrated its "legal sustainability" before the Supreme Court and has been dubbed "SCOTUSCare" by Justice Scalia who expressed his bitter disagreement from the bench.

In the next three paragraphs I offer an overview of these decisions and discuss how they affect the social sustainability of the reform. I then consider the threats posed by the lawsuits Sissel ${ }^{6}$ and Hotze, that aim to strike not only specified provisions but the entire law.

\section{Compromise n. 1: National Federation of Independent Business v. Sebelius.} The optional expansion of Medicaid

Medicaid is the largest program of health care funding for people with low income in the United States, authorized in 1965 under the Constitution's spending power. Prior to the ACA's passage, states were free to accept or decline federal Medicaid funds and to determine eligibility criteria for Medicaid; every State had different eligibility requirements based on income and other circumstances. ${ }^{7}$ The ACA, for the purpose of creating a uniform eligibility requirement, mandated that states expand their Medicaid programs and set the eligibility criterion to all households with incomes up to $138 \%$ of the poverty line. ${ }^{8}$ The Act provides that the federal government will pay 100 percent of the costs of covering the newly eligible Medicaid population until 2016, after which time the federal share tapers to 90 percent beginning in $2020{ }^{9}$

\footnotetext{
${ }^{3}$ NFIB v. Sebelius, 132 S.Ct. 2566 (2012). Chief Justice John Roberts interpreted the individual mandate as an exercise of Congress's taxation power. Thus, while it did not strike down the statute, this ruling greatly weakened it by putting constraints on how large individual mandate penalties could be and by making Medicaid expansion optional.

${ }^{4}$ Burwell v. Hobby Lobby Stores, 573 U.S. _, 134 S. Ct. 2751 (2014).

${ }^{5} 576$ U.S. (2015).

${ }^{6} 760$ F.3d 1 (D.C. Cir. 2014).

${ }^{7}$ Beik, Janet I. Health Insurance Today: A Practical Approach. Elsevier Health Sciences, 2014, p. 129.

${ }^{8}$ It corresponds to $\$ 16,105$ for a household of only 1 person, to $\$ 21,707$ for 2 person household, $\$ 27,310$ for three people and $\$ 32,913$ for four person household. See other parameters for Federal Poverty here: http://www.medicaid.gov/Medicaid-CHIP-Program-Information/By-

Topics/Eligibility/Downloads/2014-Federal-Poverty-level-charts.pdf

9 (A) 100 percent for calendar quarters in 2014, 2015, and 2016;

“(B) 95 percent for calendar quarters in 2017;

“(C) 94 percent for calendar quarters in 2018;
} 
As mentioned above, the Supreme Court found - with the Sebelius decision - that compelling the states to participate in the ACA Medicaid expansion was coercive and unconstitutional under the Spending Clause ${ }^{10}$ and left the states with a "genuine choice whether to participate in the new ACA Medicaid expansion." 11 As of April 2015, thirty states (including DC) have expanded Medicaid; nineteen are not moving forward and two states are still uncertain ${ }^{12}$ (Indiana and Utah have a pending waiver for an alternative Medicaid expansion plan).

What are the consequences of the Sebelius compromise (Medicaid optional expansion) for the sustainability of the reform?

A remarkable consequence is that many residents of states that did not expand Medicaid find themselves in what is referred to as a coverage gap: they do not qualify for states' Medicaid eligibility level, but they also do not earn enough to qualify for the subsidies and tax credits designed to make buying insurance affordable under the ACA. This is because the ACA did not foresee needing subsidies for those people since states at the time were all expected to expand Medicaid programs. ${ }^{13}$ About 4.5 million people across the country fall into this coverage gap, according to the Kaiser Family Foundation. ${ }^{14}$

The effects of this passive resistance on the sustainability of the reform are surely worthy of investigation. I believe that the coverage gap clearly represents the Achilles' heel for the sustainability of such a patchwork implementation of the reform mainly because the Administration failed to achieve the universality and equality it was originally seeking. The Kaiser Family Foundation has commented: "People in the coverage gap are likely to face barriers to needed health services or, if they do require medical care, potentially serious financial consequences. Further, the safety net of clinics and hospitals that has traditionally served the uninsured population will continue to be stretched in these states." 15 The danger is also that the uneven Medicaid expansion could be legally interpreted as unequal taxation and, as such, form the basis of future legal challenges to Obamacare. ${ }^{16}$

\section{Compromise n.2: Burwell v. Hobby Lobby Stores. No contraception mandate for religious family-owned corporations.}

Another example of legal success in limiting the implementation of core provisions of the reform is the Religious Employers Challenge. In the last two years, about 102 lawsuits have been filed in federal courts challenging the contraceptive coverage requirement. The issue arrived at the U.S. Supreme Court with the Hobby Lobby case, in which a national arts and crafts chain with over 13,000 employees challenged the contraception requirement on a moral basis. Specifically, under the Patient Protection and Affordable Care Act (ACA), employment-based group health care plans must

\footnotetext{
“(D) 93 percent for calendar quarters in 2019; and

“(E) 90 percent for calendar quarters in 2020 and each year thereafter.

${ }^{10}$ See Swendiman, Kathleen and, Evelyne P. Baumrucker, "Selected Issues Related to the Effect of NFIB v. Sebelius on the Medicaid Expansion Requirements in Section 2001 of the Affordable Care Act." Congressional Research Service, 16 July, 2012.

${ }^{11}$ Sebelius at 57.

12 "A 50-State Look at Medicaid Expansion", Families USA, accessed 10th Jul. 2015 http://familiesusa.org/product/50-state-look-medicaid-expansion ${ }^{13}$ Moulton, Kristen and Robert Gehrke. "Utah's alternative to Medicaid expansion still stalled", The Salt Lake Tribune, 29 August, 2014 (available at http://www.sltrib.com/sltrib/mobile3/58347872-219/utah-health-healthy-herbert.html.csp)

14 "Status of State Action on the Medicaid Expansion Decision", accessed $11^{\text {th }}$ Oct. 2014. http://kff.org/health-reform/issue-brief/the-coverage-gapuninsured-poor-adults-in-states-that-do-not-expand-medicaid/,

${ }^{15}$ Id.

${ }^{16}$ See for discussion Loughlin, Kevin R. "Life After Obamacare.” Onclive, last accessed 8 December 2014. http://www.onclive.com/publications/urologists-in-cancer-care/2014/August-2014/Life-After-Obamacare,
} 
provide comprehensive coverage for some FDA-approved methods of contraception which for some runs counter to Biblical teaching. ${ }^{17}$

In this landmark decision, issued on $30^{\text {th }}$ June 2014, the Supreme Court rejected the contraceptive mandate for some religious family-owned corporations, holding that requiring employers to provide their female employees with contraception violates the Religious Freedom Restoration Act of 1993.

The 5-to-4 ruling ${ }^{18}$, which applied to two companies owned by Christian families, succeeded this time in "adjusting" the law according to claimants' religious beliefs and altered the original requirement that companies offer contraceptive coverage to workers, potentially affecting millions of women.

What are the consequences of the Hobby Lobby compromise (religious employers' exemption) for the sustainability of the reform?

Walter Dellinger, Assistant Attorney General and Head of the Office of Legal Counsel under President Bill Clinton, commented: "Before the Hobby Lobby ruling women had guaranteed contraceptive coverage as part of their employment health insurance; now it is clear that their access to contraception is by no means guaranteed given the administrative complexities the court has now imposed upon". ${ }^{19}$

It is important to note that the ACA originally provided exemption to religiously affiliated non-profit organizations that objected on religious grounds to covering contraception so that the implementation of this mandate was already fragmented. Nonetheless, the decision of the Court is a clear example of unforeseen consequences of policy.

Again, where is the universal coverage that the reform was originally seeking? It is evident that the administration still needs to find the appropriate balance between religious freedom and women's rights. In this regard, the Obama administration has said that insurers have an independent legal obligation to provide contraceptive coverage. ${ }^{20}$

Furthermore, the real threat of the Hobby Lobby decision, and perhaps the one with wider effects, is - as Adam Liptak commented $^{21}$ - that it opened the door to many challenges from corporations over laws that they claim violate their religious liberty.

In her dissenting opinion, Justice Ruth Bader Ginsburg called it "a decision of startling breadth," and expressed her concerns for potential exemptions also for employers with religiously grounded objections to blood transfusions (Jehovah's Witnesses), antidepressants (Scientologists), medications derived from pigs, including anaesthesia, intravenous fluids, and pills coated with gelatine (offensive to certain Muslims, Jews, and Hindus), and vaccinations (offensive to Christian Scientists, among others). The New Yorker, in an article dated 30/09/2014, forthrightly asserts "On Hobby Lobby, Ginsburg Was Right". ${ }^{22}$ Only time will tell us how sustainable the contraception mandate really is.

\footnotetext{
${ }^{17}$ Kerwick, Jack "Backlash Against Obamacare Contraceptive Mandate", The new American, accessed 11 Oct. 2014, http:// www.thenewamerican.com/usnews/constitution/item/15891-backlash-against-obamacare-contraceptive-mandate.

${ }^{18}$ Justice Stephen G. Breyer joined Justices Sotomayor, Ginsburg and Kagan in dissent.

${ }^{19}$ Quoted in Adam Liptak, "Birth Control Order Deepens Divide Among Justices", New York Times, 3 Jul. 2014

${ }^{20}$ Pear, Robert. "A Two-Page Form Spawns a Contraceptive Showdown”, The New York Times, 12 July 2014

${ }^{21}$ Liptak, Adam. "Supreme Court Rejects Contraceptives Mandate for Some Corporations", New York Times, 30 Jun. 2014

${ }^{22}$ Toobin, Jeffrey. "On Hobby Lobby, Ginsburg Was Right.” The New Yorker, 30 Sep. 2014 (available at http://www.newyorker.com/news/dailycomment/hobby-lobbys-troubling-aftermath)
} 


\section{The Compromise n. 3: King v. Burwell The legality of IRS subsidies in federal exchanges}

The ACA encourages the states to create their own Health Insurance Exchange (a marketplace where people can compare and purchase health coverage) but, if a state fails to create an exchange that meets federal standards, the federal government provides a "fallback" federal exchange for that state, usually through the well-known platform Healthcare.gov.

State-run market exchanges are designed to perform a broad range of tasks, including the issuance of tax credits and subsidies for the purchase of health insurance plans. In May 2012, an Internal Revenue Service (IRS) rule clarified the meaning of Section 36B of the ACA which allows an individual to receive tax credits only if the individual enrols in an insurance plan through "an Exchange established by the State under section 1311 of the Patient Protection and Affordable Care Act". The IRS rule therefore extended the availability of tax credits and subsidies to federal-run market exchanges. The authors of the IRS legal challenges argue that tax credits and subsidies should not be available in federally run exchanges and the IRS rule is therefore contrary to congressional intent. In June 2015 the Court was asked to determine the correct reading of Section 36B, specifically whether the Act's tax credits are available in states that have a Federal Exchange. The Supreme Court did not compromise again and issued a firm decision to save the Act. Justice Roberts, writing for the majority, asserted that the meaning of an ambiguous text has to be interpreted in light of the broader structure of the statute and resolved that "petitioners interpretation would destabilize the individual insurance market in any State with a Federal Exchange and likely create the very 'death spiral' that Congress designed the Act to avoid." 23

The Court clearly saved the Act from an untold danger. The legal sustainability of the ACA has been affirmed for good.

King v. Burwell was an attempt to strike down the entire law. Indeed, if the federal government was not able to issue tax credits for the purchase of health insurance in federal exchanges, citizens in 36 states would had to pay an overpriced insurance premium (not benefitting from the tax credit) or, if the total cost of buying insurance exceeded eight percent of petitioners' income they would have been exempt from the Act's coverage requirement. This would have clearly been an unacceptable situation which would have led to the repeal of the Act. Proponents of these challenges seemed very optimistic: "My jaw dropped when I first saw this. This has the potential to sink Obamacare. It could make the current website problems seem minor by comparison" commented CATO Institute's Michael Cannon. ${ }^{24}$ Sandhya Somashekhar and Amy Goldstein have commented: "If the decision going against the government is upheld, it will be more damaging to the law than a Supreme Court decision last month that limited coverage of contraceptives." 25

\footnotetext{
23576 U.S.__ (2015) Syllabus.

${ }^{24}$ Quoted in Savage, David G. “Could a wording 'glitch' doom Obama's healthcare law?” The Los Angeles Times 25 Aug. 2014 http://www.latimes.com/nation/la-na-health-law-flaw-20140825-story.html.

Law professor Jonathan Adler and Cato Institute health policy expert Michael Cannon have written the most definitive explanation of the argument in favor of the plaintiffs. See also Diamond, Dan. Could This Little-Watched Court Case Sink Obamacare, California Healthline, 12 June 2013.

${ }^{25}$ Somashekhar, Sandhya and Amy Goldstein. "Federal appeals courts issue contradictory rulings on health-law subsidies", Washington Post, $22^{\text {nd }}$ June $2014 \mathrm{http} / / / \mathrm{www} . w a s h i n g t o n p o s t . c o m / n a t i o n a l / h e a l t h-s c i e n c e / f e d e r a l-a p p e a l s-c o u r t-p a n e l-d e a l s-m a j o r-b l o w-t o-h e a l t h-l a w / 2014 / 07 / 22 / c 86 \mathrm{dd} 2 \mathrm{ce}-$ 06a5-11e4-bbf1-cc51275e7f8f_story.html.
} 


\section{The radical lawsuits: Sissel $^{26}$ and Hotze $^{27}$}

The ultimate objective of Obamacare`s opponents is to strike down the entire law, not only some of its more contentious provisions. Sissel and Hotze are two major challenges attacking the reform as a whole with creative reasoning. The main argument here is that since, according to Sebelius, the individual mandate qualifies as a "tax" the ACA must be intended as a tax-raising bill and - as a consequence- it should have originated in the House of Representatives and not the Senate. Because it did not, plaintiffs argue, the law violates the Origination Clause (U.S. Constitution, Article I, Section 7), which requires that all bills for raising revenue "shall originate in the House of Representatives." What really happened with the ACA bill is a very common practice in the U.S. legislature: the so called "Shell Bill Game". ${ }^{28}$ Broadly speaking, in order to comply with the Origination Clause, the Senate takes a revenue bill passed by the House and strikes the language of the bill entirely replacing it with its own revenue bill unrelated to the one that began in the House. ${ }^{29}$ With the ACA, the House had earlier originated the "shell" bill which was subsequently replaced by the Senate health care bill containing the majority of the health care law, including the individual mandate.

\section{Sissel v. U.S. Department of Health \& Human Services (U.S. Court of Appeals for D.C. Circuit)}

Matthew Sissel, an artist from Iowa challenged the constitutionality of the ACA arguing that taxes imposed under Congress' taxing power, "not as an adjunct to a regulation of commerce or the exercise of some other enumerated power," are per se revenue-raising bills subject to the Origination Clause.

On 29th July 2014, the D.C. Circuit Court of Appeals ruled against this challenge, holding that the individual mandate tax need not have originated in the House of Representatives because it does not qualify as a "bill for raising revenue" under the Constitution. Judge Judith Rogers held that the overall purpose of the individual mandate tax was to force people to buy insurance, not to raise revenue, and therefore the constitutional requirement that it originate in the House does not apply. ${ }^{30}$ Plaintiff has filed a petition for rehearing en banc on 6 Oct. 2014.

\section{Hotze v. Burwell (U.S. District Court for the Southern District of Texas)}

The plaintiffs Steven Hotze, a Texas physician, and his company, filed suit in the U.S. District Court for the Southern District of Texas, arguing that the ACA violates the Constitution's Origination Clause. ${ }^{31}$ The district court rejected the plaintiffs' arguments, holding that the ACA is not a revenue-raising bill under the Origination Clause and, in the alternative, even if it is a revenue-raising bill, it is nonetheless constitutional because the ACA originated in the House of Representatives and the Senate's amendments to the Act were proper under the Origination Clause. ${ }^{32}$ The plaintiffs appealed to the United States Court of Appeals for the Fifth Circuit. In the same lawsuit, the plaintiff also argues that the ACA's employer mandate violates the Constitution's Takings Clause by forcing a private business owner to pay other businesses (insurance companies) without making just compensation to him for doing so. Oral argument took place on 2

\footnotetext{
${ }^{26} 760$ F.3d 1 (D.C. Cir. 2014).

27784 F.3d 984 (Fifth Circuit 2015).

${ }^{28}$ The term is used in Capitol Hill parlance.

${ }^{29}$ Kysar, Rebecca M. "The 'Shell Bill' Game: Avoidance and The Origination Clause”, 91 Wash. U. L. Rev. 659, 661 (2014)

${ }^{30}$ Sandefur, Timothy. "D.C. Circuit rules that Obamacare tax isn't a bill for raising revenue", Pacific Legal Foundation Liberty blog, 29 July 2014, http://blog.pacificlegal.org/2014/d-c-circuit-rules-obamacare-tax-isnt-bill-raising-revenue/

${ }^{31}$ See Leonard, Michael Scott. "Judge Rejects "Origination Clause' Challenge to Obamacare; Appellate Briefs Filed in Earlier Case" Westlaw Journal Health Law 3, (2014).

${ }^{32}$ Hotze v. Sebelius, 991 F.Supp.2d 864 (S.D. Tex. 2014), 113 A.F.T.R.2d 2014-533, 2014-1 USTC P 50,132.
} 
December 2014, the Court vacated the district court's judgment and remanded the case to that court with instructions to dismiss the complaint for lack of jurisdiction.

This short account of pending Origination Clause litigation undoubtedly shows that, despite the Supreme Court settlements, the legal challenges to health-care reform are not over and have the potential to further reshape the law and make impact on its implementation. As we have seen with the Sebelius and Hobby Lobby cases, the opposition has already managed to sabotage core aspects of the reform and it is therefore crucial to monitor the progress of pending challenges.

\section{The "political sustainability" dimension}

By "political sustainability" I intend the ability of the administration to protect the reform from the unceasing attacks of the Republican party but, above all, to deal with the reluctance of some states to co-operate with the federal government. In assessing the political sustainability of the reform it is therefore paramount to examine the political reaction across the 50 state legislatures and the measures put in place against the Act.

In the early days of the ACA, several states were concerned about the immediate effects that the reform would have in their territories and openly refused to co-operate with the federal government in various ways, starting with the refusal to establish state-run "Health Insurance Exchanges" or to expand Medicaid. Some states also used a questionable "emergency strategy": the enactment of state law in opposition to neglected provisions. For example, at least 5 states (Alabama, Arizona, Ohio, Oklahoma, Wyoming) have amended their own constitution to provide that the state government will not implement or enforce mandates requiring the purchase of insurance by individuals or payments by employers; ${ }^{33}$ at least 14 states have considered measures to prohibit state agencies or employees from implementing the individual mandate within the state; ${ }^{34} 19$ states even considered bills to declare the ACA null and void. ${ }^{35}$ As already said, the legitimacy of these measures is questionable but the size of the phenomenon invites reflection on possible consequences for the sustainability of the Act. The table below provides an overview of the use of "resistance practices" since 2010. For the purpose of an analytical study of the political opposition to the ACA, I have identified four main patterns of resistance:

1. refusal to establish a state-run "Health Insurance Exchanges"; 36

2. refusal to expand Medicaid; ${ }^{37}$

3. opposition to, or proposal of alternatives to the ACA, including constitutional amendments and measures prohibiting the implementation of the reform within their boundaries; ${ }^{38}$

4. proposal of bills to declare several federal laws void within their state's boundaries. ${ }^{39}$

To date, 36 states have refused to establish and take full charge of a "Health Insurance Exchange" now called "Marketplaces" and 21 have refused to expand Medicaid. The legislatures of 45 states have considered bills proposing

\footnotetext{
${ }^{33}$ Cauchi, Richard. "State Laws and Actions Challenging Certain Health Reforms", NCSL website: http://www.ncsl.org/research/health/state-lawsand-actions-challenging-ppaca.aspx.

${ }^{34}$ Id. (states are: Arizona, Florida, Georgia, Idaho, Indiana, Kansas, Louisiana, Missouri, Montana, New Hampshire, North Dakota, South Carolina, Tennessee, Virginia).

${ }^{35} \mathrm{Id}$.

${ }^{36}$ State Marketplace Decisions are tracked through review of state legislation and other Marketplace documents by the Kaiser Family Foundation. http://kff.org/health-reform/state-indicator/state-decisions-for-creating-health-insurance-exchanges-and-expanding-medicaid/.

${ }^{37}$ Id.

${ }^{38}$ Data collected using the NCSL Affordable Care Act Legislative Database powered by Lexis Nexis StateNet. http://www.ncsl.org/research/health/state-laws-and-actions-challenging-ppaca.aspx. ${ }^{39}$ Id.
} 
alternatives to the ACA. At least 19 legislatures have considered bills to declare several federal laws void within their state's boundaries. Such different methods of opposition to the federal program are growing in number and they disclose a rejuvenated skepticism of federal authority wrapped in the flag of protection of individual liberty. Adam Freedman has defined this phenomenon as "a resurgent force" of states' rights. ${ }^{40}$

From the table below, it emerges that the more "combative" states (highlighted in red), using all four "resistance strategies" are mostly southern states (Alabama, Georgia, Oklahoma, South Carolina and Texas) and states with a republican majority such as Alabama, Georgia, Indiana, Missouri (Dem. Gov.), Montana (Dem. Gov.), Oklahoma, South Carolina, Texas, Wyoming. Unsurprisingly, the more compliant states (highlighted in green), using none of the above mentioned strategies, are all northern democratic states (Connecticut, Massachusetts, Vermont) and Hawaii. The determining factor is clearly the political majority in the state legislature, and confirms the highly partisan climate surrounding the implementation of the law.

Table n. 1: State measures against the ACA

\footnotetext{
${ }^{40}$ Freedman, Adam. "Federalism, Red and Blue", City Journal, Summer 2013. Accessible at http://www.city-journal.org/2013/23_3_federalism.html.
} 


\begin{tabular}{|c|c|c|c|c|}
\hline 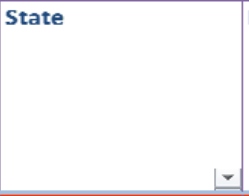 & $\begin{array}{l}\text { Refusal to establish } \\
\text { a fully state-run } \\
\text { "Health Insurance } \\
\text { Exchanges" }\end{array}$ & $\begin{array}{c}\text { Refusal to expand } \\
\text { Medicaid }\end{array}$ & $\begin{array}{l}\text { Proposal of } \\
\text { legislative } \\
\text { alternatives to } \\
\text { substantive } \\
\text { provisions in the } \\
\text { ACA }\end{array}$ & $\begin{array}{c}\text { Proposal of bills to } \\
\text { declare ACA's } \\
\text { provisions void } \\
\text { within their state's } \\
\text { boundaries }\end{array}$ \\
\hline Alabama & $\mathrm{x}$ & $\mathrm{x}$ & $\mathrm{x}$ & $x$ \\
\hline Alaska & $x$ & $x$ & $x$ & \\
\hline Arizona & $\mathrm{x}$ & & $x$ & $x$ \\
\hline Arkansas & x state-partnership & & $x$ & \\
\hline California & & & $x$ & \\
\hline Colorado & & & $x$ & \\
\hline \multicolumn{5}{|l|}{ Connecticut } \\
\hline Delaware & x state-partnership & & $x$ & \\
\hline Florida & $\mathrm{x}$ & $x$ & $x$ & \\
\hline Georgia & $x$ & $x$ & $x$ & $x$ \\
\hline \multicolumn{5}{|l|}{ Hawaii } \\
\hline Idaho & & $x$ & $x$ & $x$ \\
\hline Illinois & & & $x$ & \\
\hline Indiana & $\mathrm{x}$ & pending waiver & $x$ & $x$ \\
\hline lowa & x state-partnership & & $x$ & $x$ \\
\hline Kansas & $\mathrm{x}$ & $x$ & $\mathrm{x}$ & \\
\hline Kentucky & & & $x$ & \\
\hline Louisiana & $x$ & $x$ & $x$ & \\
\hline Maine & $x$ & $x$ & $x$ & $x$ \\
\hline Maryland & & & $x$ & \\
\hline \multicolumn{5}{|l|}{ Massachusetts } \\
\hline Michigan & x state-partnership & & $x$ & \\
\hline Minnesota & & & $x$ & \\
\hline Mississippi & $x$ & $x$ & $x$ & \\
\hline Missouri & $x$ & $x$ & $x$ & $x$ \\
\hline Montana & $x$ & $x$ & $x$ & $x$ \\
\hline Nebraska & $x$ & $x$ & $x$ & $x$ \\
\hline Nevada & X Federally-supported & & & \\
\hline New Hampshire & x state-partnership & & $\mathrm{x}$ & \\
\hline New Jersey & $\mathrm{x}$ & & $x$ & $x$ \\
\hline New Mexico & X Federally-supported & & $x$ & \\
\hline New York & & & $x$ & \\
\hline North Carolina & $x$ & $x$ & $x$ & \\
\hline North Dakota & $x$ & & $\mathrm{x}$ & $x$ \\
\hline Ohio & $x$ & & $x$ & \\
\hline Oklahoma & $x$ & $x$ & $x$ & $x$ \\
\hline Oregon & Federally-supported & & $x$ & $x$ \\
\hline Pennsylvania & $\mathrm{x}$ & & $x$ & \\
\hline Rhode Island & & & $\mathrm{x}$ & \\
\hline South Carolina & $x$ & $x$ & $x$ & $x$ \\
\hline South Dakota & $x$ & $x$ & $x$ & \\
\hline Tennessee & $\mathrm{x}$ & $x$ & $x$ & \\
\hline Texas & $x$ & $\mathrm{x}$ & $x$ & $x$ \\
\hline Utah & $x$ & Open Debate & $x$ & $x$ \\
\hline \multicolumn{5}{|l|}{ Vermont } \\
\hline Virginia & $x$ & $x$ & $x$ & \\
\hline Washington & & & $x$ & \\
\hline West Virginia & x state-partnership & & $x$ & $\mathrm{x}$ \\
\hline Wisconsin & $\mathrm{x}$ & $x$ & $x$ & \\
\hline Wyoming & $x$ & $x$ & $x$ & $x$ \\
\hline
\end{tabular}


What are the implications of these "resistance strategies" for the political sustainability of the Act?

With regard to the refusal to establish a state-run "Health Insurance Exchanges" and to expand Medicaid, data indicate a high level of state distrust and uncertainty about the outcome of the reform. Most of the states perceived that the costs of running state exchanges or expanding Medicaid were too high or uncertain and the putative benefits illusory. ${ }^{41}$ The federal government has performed well in the establishment and administration of a common federal marketplace through the online platform "healthcare.org", and despite initial technical issues, on 16 ${ }^{\text {th }}$ Dec. 2014 CNBC reported the enrolment of 2.466 million of people since $15^{\text {th }}$ November. ${ }^{42}$ The implications of Medicaid non- expansion have been discussed above in the analysis of the Sebelius compromise and it is worth repeating that the coverage gap remains the major issue for the social sustainability of the reform, as it does not allow the creation of a uniform, equal and quasiuniversal health care system.

With regard to the implications of measures against the ACA (including constitutional amendments, legislation prohibiting state agencies or employees from implementing the individual mandate and nullification bills) it is important to highlight that their enactment is legally controversial and therefore also their impact is uncertain. On one hand, under the Supremacy Clause, state law contrary to federal law should be pre-empted and therefore void. On the other hand, the anti-commandeering doctrine established by Supreme Court in Prigg v. Pennsylvania ${ }^{43}$, New York v. United States ${ }^{44}$ and Printz v. United States ${ }^{45}$ would prevent the federal government from mandating that states participate in enforcing federal law. In light of these assertions, it would seem that states cannot openly declare the federal law "null" but they could passively oppose the operation of the same within their boundaries by refusing to use their enforcement resources. ${ }^{46}$

In conclusion, legislation against the ACA has only a symbolic value; it creates political pressure and maintains the issue's long-term political salience ${ }^{47}$ but has not been demonstrated to have an actual impact on the political sustainability of the reform. State legislation against the individual mandate, for example, has not prevented the implementation of this provision in the states and nullification bills have not even been effective in obtaining "flexibility" or the so called "compromises" achieved through court litigation. From this perspective, the political opposition of the states cannot be considered a real threat for the sustainability of the reform but only an emblematic demonstration of rejuvenated skepticism of the federal programmes.

\section{Legal sustainability, political sustainability and the effects on social sustainability}

The analysis of legal challenges has shown how the decisions of the Court, in an escalation of assertiveness, have ensured the survival of the reform and therefore the legal sustainability. However, in its artful Sebelius compromise, the Court has

\footnotetext{
${ }^{41}$ Dinan, John. "Implementing Health Reform: Intergovernmental Bargaining and the Affordable Care Act" Publius: The Journal of Federalism 44 (Summer 2014): 399-425.

${ }^{42}$ Mangan, Dan. "HealthCare.gov enrollment hits nearly 2.5 million”, CNBC website, $16^{\text {th }}$ Dec. 2014 (http://www.cnbc.com/id/102273913\#.)

${ }^{43} 41$ U.S. 539 (1842). The Court held that states were not required to enforce federal slavery laws.

${ }^{44} 505$ U.S. 144 (1992). The Court held that Congress could not require states to enact specified waste disposal regulations.

${ }^{45} 521$ U.S. 898 (1997). The Court held that the federal government could not command state law enforcement authorities to conduct background checks on prospective handgun purchasers. "The federal government may not compel the states to enact or administer a federal regulatory program."

${ }^{46}$ This is a complicated federalism issue. For more case law about the Supremacy clause see Perez v. Campbell, 402 U.S. 637, 647 (1971), Rice v.

Santa Fe Elevator Corp., 331 U.S. 218 (1947) and for a parallel with medical marijuana decriminalization see Robert A. Mikos, On the Limits of Supremacy: Medical Marijuana and the States' Overlooked Power to Legalize Federal Crime, 62 Vand. L. Rev. 1421, 1432 (2009).

${ }^{47}$ Card, Ryan. "Can States "Just Say No" to Federal Health Care Reform? The Constitutional and Political Implications of State Attempts to Nullify Federal Law", BYU L. Rev. 1795 (2010)

Available at: http://digitalcommons.law.byu.edu/lawreview/vol2010/iss5/7.
} 
altered the original operation of the law. It is my opinion that Sebelius ensured legal sustainability at the expenses of social sustainability. ${ }^{48}$ If we take equality as a determinant factor to assess sustainability, the coverage gap (result of the optional expansion of Medicaid decided in Sebelius) is a manifest failure and can be interpreted as an unintended consequence of policy. The same can be said of Hobby Lobby; granting religious employers exemption from contraceptive coverage further undermines the equal coverage that the reform was originally seeking.

King v. Burwell was a change of direction. The Court has openly expressed support for the reform in a very sophisticated challenge. Even if the assertiveness of King v. Burwell cannot correct the social consequences of Sebelius and Hobby Lobby compromises, I would emphasize that not only has the legal sustainability been ensured once and for all but also that the Court's declaration at the conclusion of the majority opinion, "Congress passed the Affordable Care Act to improve health insurance markets, not to destroy them" 49 demonstrates an express concern for social sustainability.

My research into state legislative resistance to the ACA has investigated the political sustainability of the reform and found that the phenomenon can be considered an emblematic demonstration of a rejuvenated skepticism of federal programmes. Traditionally, social policies including healthcare, health insurance, public health regulations were the exclusive province of the states. ${ }^{50}$ This dynamic changed in the New Deal and Great Society eras, when the federal government took an increasingly larger role in regulating and financing social policies. Since then, the so called "welfare state" has evolved into the current form of "regulatory state" in which centralized rule-making, rule-monitoring and ruleenforcement leave to decentralized agencies the task of implementing the law. ${ }^{51}$

However, the centralized regulation of social programmes like healthcare is currently facing a strong resistance by many states that refuse to cooperate with the central government and implement the federal law. The main reason for the resistance is political; most of the states opposing the reform are Republican states with long traditions of individualism, self-government and autonomy from Washington. I had the opportunity to meet state legislators and bill drafters at the 2014 NCSL seminar in Richmond, VA ${ }^{52}$ and the most common response to my question "Why did you not expand Medicaid? At the end of the day they promised money, it is money from the Feds..." was: "Because we don't believe that Washington can keep its promises. We prefer Obamacare to be their failure, not our disaster".

Distrust in the federal government and the strong tradition of self-government make the states reluctant to accept federal funds and foresee an imminent failure of the program. Red states believe that the Affordable Care Act is not sustainable and needs extensive revisions. State skepticism is not limited to health care regulations but extends to other federal regulatory programmes (gun control, abortion, immigration, death penalty, drug control). Since 2010, at least 200 nullification bills have been introduced across the 50 legislatures on 11 issues alone. ${ }^{53}$

\footnotetext{
48 According to the Western Australia Council of Social Services (WACOSS) definition: "Social sustainability occurs when the formal and informal processes; systems; structures; and relationships actively support the capacity of current and future generations to create healthy and liveable communities. Socially sustainable communities are equitable, diverse, connected and democratic and provide a good quality of life.".

${ }^{49}$ King v. Burwell 135 S.Ct. 2480, 2496 (U.S.,2015).

${ }^{50}$ See generally Starr, Paul. The social transformation of American Medicine 235-90, 367-74 (1982); and also Jost, Timothy S. and Mark A. Hall, "The Role of State Regulation in Consumer-Driven Health Care" 31 AM. J.L. \& MED. 395, 399 (2005) ("Despite the variety of ... approaches to federalism, the general trend is toward greater federal involvement in health insurance regulation.").

${ }^{51}$ See Mabbett, D."The regulatory state and the welfare state." in Levi-Faur, D. (Ed.) Handbook on the Politics of Regulation, ed. David Levi-Faur. Edward Elgar, Cheltenham,(2011).

${ }^{52}$ National Conference of State Legislatures, LSSS \& RACSS seminar, 6-8 Oct. 2014 .

53 See Tabachnick, R. Nullification, Neo-Confederates, and the Revenge of the Old Right, PolitiCAL RESEARCH ASSOCIATES (Nov. 22, 2013) http://www.politicalresearch.org/2013/11/22/nullification-neo-confederates-and-the-revenge-of-the-old-right/\#sthash.nIGEX7fk.3yHXmtz5.dpbs.
} 
What can Washington do to rebuild trust in federal programmes and achieve a durable and effective federal-state relationship? Washington should take into account the diversity of 50 states' needs and maybe consider the appropriateness of $a d-h o c$ negotiations with every single state. The key to social sustainability in the United States lies in allowing selfexpression of the state governments. I would suggest that states are more likely to trust a national government that considers them individually, that is ready to negotiate and adapt the law to particular circumstances than as simply one among fifty.

$21^{\text {st }}$ century federalism requires flexibility, compromises and concessions. After all, human beings tend to trust only those who consider them special; in the same way, states as complex aggregations of human beings are most likely to place trust in a federal government that is prepared to take account of their individuality as proud sovereign states.

\section{ABOUT THE AUTHOR}

Ilaria Di Gioia is a PhD researcher in American Law at Birmingham City University and Graduate Teaching Assistant for Law of the European Union. Her research investigates the ideological and political reasons of the states' aversion to the enactment of Affordable Care Act and conceptualizes the resistance in the bigger picture of opposition to the intervention of the federal government in social policies. Before joining Birmingham City University, Ilaria interned at the Italian Embassy in Washington, DC and at the United Nations System Staff College, Turin, Italy.

\section{Bibliography}

\section{Electronic Sources}

Cauchi, Richard. State Laws and Actions Challenging Certain Health Reforms, National Conference of State Legislature. Accessed Dec. 29th 2015. http://www.ncsl.org/research/health/state-laws-and-actions-challengingppaca.aspx.

Diamond, Dan. Could This Little-Watched Court Case Sink Obamacare. California Healthline, Accessed Jun. 12th 2013. http://www.californiahealthline.org/road-to-reform/2013/could-this-little-watched-court-case-sink-obamacare

Families USA. A 50-State Look at Medicaid Expansion. Accessed Jul.10 ${ }^{\text {th }}, 2015$ http://familiesusa.org/product/50-statelook-medicaid-expansion.

Kaiser Family Foundation. Status of State Action on the Medicaid Expansion Decision. Accessed Dec. $29^{\text {th }} 2015$. http://kff.org/health-reform/state-indicator/state-activity-around-expanding-medicaid-under-the-affordable-care-act/.

Loughlin, Kevin R. Life After Obamacare. Onclive. Accessed Dec. $8^{\text {th }} 2014$.

http://www.onclive.com/publications/urologists-in-cancer-care/2014/August-2014/Life-After-Obamacare.

Mangan, Dan. HealthCare.gov enrollment hits nearly 2.5 million, CNBC. Accessed 6 ${ }^{\text {th }}$ Dec. 2014.

http://www.cnbc.com/id/102273913\#. 
National Conference of State Legislatures. Affordable Care Act Legislative Database. Accessed Dec. $29^{\text {th }} 2015$.

http://www.ncsl.org/research/health/state-laws-and-actions-challenging-ppaca.aspx.

Sandefur, Timothy. D.C. Circuit rules that Obamacare tax isn't a bill for raising revenue. Pacific Legal Foundation Liberty blog. Accessed Jul. 29th 2014. http://blog.pacificlegal.org/2014/d-c-circuit-rules-obamacare-tax-isnt-bill-raisingrevenue/.

Tabachnick, R. Nullification, Neo-Confederates, and the Revenge of the Old Right, Political research associates. Accessed Dec. 29, 2015. http://www.politicalresearch.org/2013/11/22/nullification-neo-confederates-and-the-revengeof-the-old-right/\#sthash.nIGEX7fk.3yHXmtz5.dpbs.

\section{Journals}

Card, Ryan. "Can States "Just Say No" to Federal Health Care Reform? The Constitutional and Political Implications of State Attempts to Nullify Federal Law", BYU L. Rev. 1795 (2010)

Dinan, John. "Implementing Health Reform: Intergovernmental Bargaining and the Affordable Care Act" Publius: The Journal of Federalism 44 (Summer 2014): 399-425.

Jost, Timothy S. and Mark A. Hall, "The Role of State Regulation in Consumer-Driven Health Care" 31 AM. J.L. \& MED. 395, 399 (2005).

Kysar, Rebecca M. “The 'Shell Bill’ Game: Avoidance and The Origination Clause”, 91 Wash. U. L. Rev. 659, 661 (2014).

Leonard, Michael Scott. "Judge Rejects "Origination Clause' Challenge to Obamacare; Appellate Briefs Filed in Earlier Case" Westlaw Journal Health Law 3, (2014).

\section{Newspapers}

Adam Liptak, "Birth Control Order Deepens Divide Among Justices", New York Times, Jul. $3^{\text {rd }}, 2014$.

David G. "Could a wording 'glitch' doom Obama's healthcare law?" The Los Angeles Times Aug. 25, 2014.

http://www.latimes.com/nation/la-na-health-law-flaw-20140825-story.html.

Freedman, Adam. "Federalism, Red and Blue", City Journal, Summer 2013. http://www.cityjournal.org/2013/23_3_federalism.html.

Liptak, Adam. "Supreme Court Rejects Contraceptives Mandate for Some Corporations", New York Times, June 30" 2014.

Moulton, Kristen and Robert Gehrke. Utah's alternative to Medicaid expansion still stalled", The Salt Lake Tribune, August $29^{\text {th }}$, 2014. http://www.sltrib.com/sltrib/mobile3/58347872-219/utah-health-healthy-herbert.html.csp).

Pear, Robert. “A Two-Page Form Spawns a Contraceptive Showdown”, The New York Times, July 12th, 2014. 
Somashekhar, Sandhya and Amy Goldstein. "Federal appeals courts issue contradictory rulings on health-law subsidies", Washington Post, June 22 ${ }^{\text {nd }}$, 2014. http://www.washingtonpost.com/national/health-science/federal-appeals-court-paneldeals-major-blow-to-health-law/2014/07/22/c86dd2ce-06a5-11e4-bbf1-cc51275e7f8f_story.html.

Toobin, Jeffrey. “On Hobby Lobby, Ginsburg Was Right.” The New Yorker, Sep. 30" 2014

http://www.newyorker.com/news/daily-comment/hobby-lobbys-troubling-aftermath.

\section{Books}

Beik, Janet I. Health Insurance Today: A Practical Approach. Elsevier Health Sciences, 2014.

Mabbett, D. "The regulatory state and the welfare state." in Handbook on the Politics of Regulation, edited by David Levi-Faur and Edward Elgar, Cheltenham (2011).

\section{Magazines}

Kerwick, Jack. "Backlash Against Obamacare Contraceptive Mandate" The new American, Jul. $3^{\text {rd }}$ 2013, http:// www.thenewamerican.com/usnews/constitution/item/15891-backlash-against-obamacare-contraceptive-mandate.

\section{Memorandum}

Swendiman, Kathleen and, Evelyne P. Baumrucker, "Selected Issues Related to the Effect of NFIB v. Sebelius on the Medicaid Expansion Requirements in Section 2001 of the Affordable Care Act." Congressional Research Service, 16 July, 2012. 